\title{
EVALUATION OF COTTON STALKS DESTROYERS
}

\section{ALOISIO BIANCHINI ${ }^{1}$, PEDRO H. DE M. BORGES ${ }^{2}$}

\begin{abstract}
The destruction of the cotton crop residues (cotton stalks) is a mandatory procedure in Brazil for prophylactic issues, but is a subject unexplored by the research and there are few studies that deal with this issue. However, this is not encouraged in recent decades, studies aimed at developing and evaluating equipment for this purpose. The present study had the objective to evaluate six methods for mechanical destruction of cotton crop residues. Each method was defined based on the principle of operation of the active parts of the equipment, which were tested in medium texture soil and in a clayey one. The variables used to evaluate the efficiency of the equipment were the regrowth rate, the theoretical field capacity and energy demand. The equipment with convergent concave disks (DCC) and flat cutters discs from manufacturer A (CPS-a) showed the best results in cotton stalks destruction in both soil types. The harrow disc (GPD) was efficient only in clay soil. It was concluded that the equipment with convergent concave disks, among those tested, was the most efficient to destroy cotton stalks, regardless of soil type, and that the harrow disc was not included among the best performers.
\end{abstract}

KEYWORDS: Cotton stalk; machine performance; uprooting cotton stalks; cotton stalk puller.

\section{AVALIAÇÃO DE DESTRUIDORES DE RESTOS CULTURAIS DO ALGODOEIRO}

RESUMO: A destruição dos restos culturais do algodoeiro (soqueira) é um procedimento, por questões profiláticas, obrigatório no Brasil, mas é um assunto pouco explorado pela pesquisa e são escassos os trabalhos que tratam deste tema. No entanto, este fato não estimulou, nas últimas décadas, estudos que tenham como objetivo desenvolver ou avaliar equipamentos com esta finalidade. O presente estudo teve como objetivo avaliar seis equipamentos para a destruição mecânica dos restos culturais do algodoeiro. Eles foram classificados segundo o princípio de funcionamento de seus órgãos ativos e foram testados em solos de textura média e argilosa. Os equipamentos testados foram uma grade pesada de discos, dois destruidores de duplo disco planos cortadores, dois destruidores com lâmina plana e um destruidor de duplos discos concorrentes As variáveis utilizadas para avaliar a eficiência dos equipamentos foram o índice de rebrota, a capacidade de campo teórica e a demanda energética. O equipamento com discos côncavos convergentes (DCC) e com discos planos cortadores do fabricante A (DPC-a) apresentaram os melhores desempenhos na destruição de soqueiras de algodão, nos dois tipos de solo. A grade pesada de discos (GPD) foi eficiente apenas no solo argiloso. Concluiu-se que o equipamento com discos côncavos convergentes foi, entre os testados, o mais eficiente para destruir soqueiras de algodão, independentemente do tipo de solo, e que a grade pesada de discos não constou entre os de melhor desempenho.

PALAVRAS-CHAVE: soqueiras; desempenho de máquinas; destruidor de algodoeiro; arrancador de algodoeiro.

\section{INTRODUCTION}

The destruction of the cotton crop residues (stalks) is a prophylactic measure, to be held immediately after harvest and must be efficient to avoid the permanence or proliferation of host plants for pests and diseases. This procedure became mandatory in Brazil since 1953 (STEPS,

\footnotetext{
${ }^{1}$ Prof. Associado Departamento de Solos e Engenharia Rural, Faculdade de Agronomia, Veterinária e Zootecnia, Universidade Federal de Mato Grosso, Av. Fernando Correa da Costa, 2367, 78060-900, Cuiabá, MT; bianchi@ufmt.br.

${ }^{2}$ Prof. Associado Departamento de Solos e Engenharia Rural, Faculdade de Agronomia, Veterinária e Zootecnia, Universidade Federal de Mato Grosso, Av. Fernando Correa da Costa, 2367, 78060-900, Cuiabá, MT. 
1977) and in 1993 by ministerial order, supervision was delegated to States that set the deadline for the permanence of stalks in the field. In the states of Mato Grosso, Bahia, Mato Grosso do Sul and Goiás this date is 31 August each year.

The destruction of the cotton crop residues interrupts the cycle of pests and diseases affecting the crop and reduces the potential for damage to crops the following year. The plant cotton if not eliminated totally can sprout and become a source of inoculums for diseases or serve as a host for pests. Keeping the plants in the crop field allows them to produce new blossoms and host, for example, the boll weevil (Anthonomus grandis Boheman), maintaining high rates of the pest population in the offseason (BIANCHINI, 2005). The destruction of the plants after harvest became one of the main recommendations for cultivation of cotton in areas infested by the weevil, because it is through rational coexistence with this pest (EMBRAPA, 2010).

The removal of stalks, although mandatory prophylactic measure, is a subject little explored by research and haven't stimulated, in recent decades, studies that aim to develop or evaluate equipment for this purpose.

SILVA et al. (1999) studied various mechanical methods and observed that plowing with or without mowing were not different statistically from the manual uprooting, which showed an average re-growth rate of $1.8 \%$ for two consecutive years of study. BIANCHINI (2006) developed a prototype destroyer of stalks cotton, which was able to eliminate the remnants of that culture, in a single operation and with little soil disturbance.

The work of SAGLAM et al. (2010) evaluated the performance of three devices for the destruction of stalks, being a vertical shaft rotary mowers, using chain as active parts, a hoe rotary trimmer blades vertical and horizontal axis stalks which showed the best performance with 0,8 remaining plants per square meter., which showed the best performance with 0,8 remaining plants per square meter.

MOSTOFI SARKARI \& MINAEE (2008) studying a device with two concave discs converging, concluded that the best angle of inclination of the disks was $30^{\circ}$, with destruction of $95.4 \%$ of the plants and the best horizontal angle was $17^{\circ}$, with $941 \%$ efficiency. MANIAN et al. (2004) evaluated the effectiveness of the pull-off equipment with active inclined discs, varying the speed of operation and the rotation angle of inclination of the wheels and obtain a maximum value of destruction and of $86.63 \%$ stalks for feed rate machine of $1.2 \mathrm{~km} \mathrm{~h}^{-1}$ with $140 \mathrm{rpm}$ rotation and tilt angle of $30^{\circ}$ of the discs.

Systems destruction of cotton stalks adopted today by the farmers of the Brazilian cerrado, involves two steps. At first the plants receive the action of rotary mower and in the second, are effectively destroyed by mechanical action or the use of herbicides. In the Brazilian cerrado is heavy reliance on the use of disk harrows to perform such task at end of the cycle.

The condition of dry soil at the time of disposal, due to the effects of soil detachment and the cost of operation as well as the environmental risk due to indiscriminate use of herbicides show the need to develop and investigate new equipment for this purpose. This problem motivated the present work to evaluate the performance and efficiency of some equipment developed in Brazil for the elimination of crop residues of cotton.

\section{MATERIAL AND METHODS}

The research was conducted at the farm Pirassununga located in Campo Verde - MT, Brazil

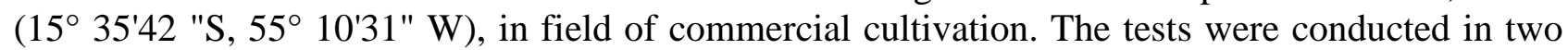
distinct areas, sandy soil, with $17.1 \%$ clay, and the other, clay soil with clay content of $43.8 \%$. At the time the tests were taken randomly from each 10 samples for the experimental determination of the water content in the soil by the standard drying oven method (EMBRAPA, 1997). 
The sandy soil was friable at the time of testing, with a water content of $22.3 \%$, but the area clayey, however, had a little dry, with average moisture of $28.4 \%$. Both soils were classified as Red Latosoil Haplortox.

The crop was installed in mid-December; with row spacing of $0.9 \mathrm{~m}$ and I average density of 10.2 plants $\mathrm{m}^{-1}$. The crop was harvested in mid-July the following year, through automotive harvester, picker type and research conducted immediately after the harvest.

The work involved the collaboration of three agricultural machinery manufacturers, who provided, regulated and performed testing of their equipment. The companies provided five machines, which were identified by their active organs, since it is these that determine the form of performance of the equipment on the ground.

Two of equipment (supplied by different manufacturers), with $4.5 \mathrm{~m}$ working width (5 rows of cotton), had five active parts, each one, by two flat discs cutters, who work with a sense of rotation opposite and partially overlapping. The set works with angles up to $10^{\circ}$ from the horizontal angle (suction) which enables them to keep in constant contact with the soil.

The discs rotate were driven by hydraulic motors which are connected to the hydraulic system of the tractor remote control. They are fixed to a rectangular chassis, coupled to the hydraulic system of the tractor three-point and each operates in a single row of plants in subsurface soil, cutting the plant in the area of the leap.

Two other testing equipment (supplied by the same manufacturer), subsoiler type with four $500 \mathrm{~mm}$ blades, working at depths of up to $200 \mathrm{~mm}$ parallel to the ground surface. The blade thanks to its angle of $20^{\circ}$ (angle of attack) cut the tap roots of cotton at the same time mobilizes the soil. These devices had useful working width of $3.6 \mathrm{~m}$ (4 rows of cotton) and were mounted on the tractor system three-point hitch. The last equipment has been tested as active parts two concave discs (disc of a plow, 28") arranged in a convergent way, running the destruction of stalks cotton. In each active organ, the discs were placed in a staggered and competitors with their concavities. In this equipment was used five active parts set in a bar tool holder, coupled to the tractor by means of three point hydraulic lift.

In addition to the equipment described a disk harrow of 16 discs $0.762 \mathrm{~m}$ in diameter (30 inches), weight of 32,373 $\mathrm{N}$ (3,300 kgf) and a working width of $2.3 \mathrm{~m}$ was introduced in the experiment, as a evidence, to be the method adopted by most cotton farmers of the cerrado.

We used three tractors: A Case, Model MXM165 of $121.36 \mathrm{~kW}$ (165 hp) rated power, a John Deere, model 7505 of 102.97 kW (140 hp) and New Holland, Model 8030, 90, 47 kW (123 hp). All tractors were at maximum ballast capacity. Was in the charge of the technical staff of each manufacturer to choose the most suitable for your tractor equipment and make the necessary adjustments and perform the tests.

The plots were mowing before that would be worked by devices that require this operation was carried out by means of a crop residue chopper (rotary mowers horizontal axis), JAN brand, model 2300 triton.

According to the operating principle of the equipment was set to the six following mechanical destruction of cotton stalks listed in Table 1. The evaluation of these procedures based on efficiency during operation and performance indicators as theoretical field capacity and energy demand.

The efficiency of equipment in the destruction of cotton stalk was determined by Equation 1:

$$
\text { Ef }=100-\text { IR }
$$

Where:

Eve: Efficiency in destruction of stalks (\%);

IR: Index of regrowth (\%). 
The regrowth rate, in turn, was calculated by Equation 2:

$$
\mathrm{IR}=\frac{\left(\mathrm{NP}_{\mathrm{i}}-\mathrm{NP}_{\mathrm{f}}\right)}{\mathrm{NP}_{\mathrm{i}}} \cdot 100
$$

Where:

NPI: Number of plants per meter before the passage of the equipment;

NPF: Number of plants per meter remaining after 60 days.

TABLE 1. Operational principle and identification of the procedures used for the mechanical destruction of cotton stalks in Campo Verde - MT

\begin{tabular}{lc}
\hline \multicolumn{1}{c}{ Operacional príncipe } & Identification \\
\hline Flat disks cutters (Manufacturer A) & DPC-a \\
Flat disks cutters (Manufacturer B) & DPC-b \\
Concave disks converging & DCC \\
Heavy disk harrow & GPD \\
$\begin{array}{l}\text { Subsoiler blade } \\
\text { Subsoiler blade + crusher plant remains }\end{array}$ & SL \\
\hline
\end{tabular}

Since the literature does not refer to a minimum value of the re growth rate, which would be suitable for advancement or dissemination of pests at alarming levels, in this work it was adopted the procedure with re growth rate equal to or less than $2 \%$ would be considered excellent, as were the rates achieved by the best equipment tested and considered by professionals connected to cotton production as being excellent; greater than $2 \%$ and less than or equal to $5 \%$, it was considered suitable to be approximately twice the index generally considered excellent; content greater than $5 \%$ were considered inefficient since the number of remaining plant is high, more than 4,000 plants per hectare.

The theoretical field capacity was estimated according BALASTREIRE (2005) as being:

$$
\mathrm{CC}_{\mathrm{t}}=\frac{\mathrm{V} \cdot \mathrm{L}}{10}
$$

Where:

CCT: theoretical field capacity $\left(\right.$ ha $\mathrm{h}^{-1}$ );

$\mathrm{V}$ : speed of operation of the mechanized assembly $\left(\mathrm{km} \mathrm{h}^{-1}\right)$ and

$\mathrm{L}$ : Working width of the set (m).

The operating speed was obtained based on the time taken to travel a distance of $30 \mathrm{~m}$ within the plot during rehearsals after your dynamic equilibrium.

The energy demand required by each set was obtained as a function of the maximum power available at the drawbar of the tractor and the theoretical field capacity of the equipment. The maximum power available at the drawbar of each tractor used was determined according to their available power in TDP, given by the manufacturer, tractor efficiency of $70 \%$ and the loss of power defined by ASABE and presented by BALASTREIRE (2005), is thus given by:

$$
\mathrm{D}_{\mathrm{e}}=\frac{\mathrm{P}}{\mathrm{CC}_{\mathrm{t}}}
$$


Where:

$\mathrm{D}_{\mathrm{e}}$ : Energy demand $\left(\mathrm{kWh} \mathrm{ha}^{-1}\right)$;

P: Maximum drawbar power $(\mathrm{kW})$ and

CCt theoretical field capacity $\left(\mathrm{ha}^{-1}\right)$.

The six treatments were arranged according to a randomized block design with 11 replications, totaling 66 experimental units for each type of soil in the experiment was to evaluate the efficiency of equipment in the destruction of stalks. The plots had a length of $50 \mathrm{~m}$ and a width of $9 \mathrm{~m}$, with a floor area of $270 \mathrm{~m}^{2}$.

Among the blocks there was a distance of $10 \mathrm{~m}$ for turning the machinery. The tests for field capacity and energy demand, in turn, were conducted in an area adjacent to the other experiment, but adopting randomized design with six replicates for each of the six treatments. In the analysis of variance and comparison of the averages were applied tests $\mathrm{F}$ (Fisher) and Tukey at 5\% probability. To evaluate the efficiency of the methods considering the soil type was used t-test (Student) at 5\% probability for two independent samples. Data normality was verified by Lilliefors test and homoscedasticity by evidence of Hartley, Cochran y Bartlett.

\section{RESULTS AND DISCUSSION}

The sandy soil was the wettest in the tests, compared to clay soil, although its water content was lower, $22.3 \%$, against $28.4 \%$ of the clay soil. This occurred by the fact that soils with large amounts of sand reached field capacity with less water. Therefore, loamy soil of the area was more coherent with respect to the sandy soil, which showed friable behavior.

The performance evaluation of equipment studied was conducted considering each attribute used in the present study.

The evaluation results of the re-growth of the cotton crop residues can be found in Tables 2 (summary of analysis of variance) and Table 3. Analysis of variance showed that between treatments was at least one of the remaining which differed at $1 \%$ probability of error. Thus, we proceeded to the analysis of means between treatments.

TABLE 2. Summary of analysis of variance for efficiency of the cotton stalks destructions procedures evaluated in cotton post-harvest in sandy soiland clay soils.

\begin{tabular}{|c|c|c|c|c|c|c|}
\hline \multirow{2}{*}{ Source Change } & \multicolumn{3}{|c|}{ Sandy soil } & \multicolumn{3}{|c|}{ Clayey soil } \\
\hline & GL & QM & $\mathrm{F}$ & GL & QM & $\mathrm{F}$ \\
\hline Treatment & 5 & 754,16 & $16,1^{* *}$ & Cinco & 543,90 & $16,9 * *$ \\
\hline Block & 10 & 102,97 & $2,2^{*}$ & 10 & 60,43 & $1,9 *$ \\
\hline Error & 50 & 46,83 & & 50 & 32,01 & \\
\hline Total & 65 & & & 65 & & \\
\hline
\end{tabular}

* And ** significant at $1 \%$ and $5 \%$ probability of error, respectively, by $\mathrm{F}$ test

Efficient destruction of stalks varied between $99.55 \%$ and $77.51 \%$, showing great difference performance between the devices tested (Table 3). Devices with active parts type concave discs convergent (DCC) and flat disk coulter, the manufacturer (DPC-a) showed the best results in the destruction of stalks cotton, both in flat disk coulter, as the soil clayey.

Devices with active parts type concave disks convergent (DCC) and flat disk coulter, the manufacturer A (DPC-a) showed the best results in the destruction of stalks cotton, both sandy soil, as the soil clayey. The performance of these devices was not affected by soil type. These devices showed efficiencies higher than those obtained by MANIAN et al. (2004), which reached a maximum value of $86.63 \%$, using active disks inclined and MOSTOFI SARKARI \& MINAEE (2008) with concave disks arranged in a convergent manner, with destruction of $95.4 \%$ of the 
plants. SAGLAN et al. (2010) found the stay of 4 plants m-2 after the destruction of the cotton crop residues with vertical axis rotary mowers, using current and active parts. When used a rotary mowers horizontal axis remaining 0.8 plants $\mathrm{m}^{-2}$ and, when a rotary hoe with vertical blades, 8 plants $\mathrm{m}^{-2}$.

TABLE 3. Efficiency and classification of the cotton stalks destructions procedures evaluated in cotton post-harvest in sandy soil and clay soils.

\begin{tabular}{|c|c|c|c|c|}
\hline \multirow{4}{*}{ Procedures } & \multicolumn{4}{|c|}{ Results } \\
\hline & \multicolumn{2}{|c|}{ Efficiency (\%) } & \multicolumn{2}{|c|}{ Classification } \\
\hline & \multicolumn{2}{|c|}{ Texture } & \multicolumn{2}{|c|}{ Texture } \\
\hline & Sandy soil & Clayey & Sandy soil & Clayey \\
\hline$\overline{D C C}$ & $99,55 \mathrm{Aa}$ & 99,46 Aa & Very effective & Very effective \\
\hline DPC-a & $99,51 \mathrm{Aa}$ & 98,58 Аа & Very effective & Very effective \\
\hline DPC-b & $91,14 \quad b$ & nd & Inefficient & nd \\
\hline GPD & $87,63 \mathrm{Bb}$ & $96,80 \mathrm{Aa}$ & Inefficient & Efficient \\
\hline $\mathrm{SL}+\mathrm{T}$ & $87,02 \mathrm{Ab}$ & $89,83 \mathrm{Ab}$ & Inefficient & Inefficient \\
\hline SL & $77,51 \mathrm{Bc}$ & $88,13 \mathrm{Ab}$ & Inefficient & Inefficient \\
\hline
\end{tabular}

Means followed by the same lower case letter in the column do not differ statistically by the Tukey test (p $<0.05$ ); Means followed by the same capital letter in the line do not differ statistically by t-test $(p<0.05)$; nd $=$ not determined. (DPC-a) Flat disk coulter Manufacturer (A), (DPC-b) flat disk coulter (Manufacturer B); (DCC) converging concave discs; (GPD) Heavy grade discs; (SL) subsoiler; (SL + T) subsoiler + Crusher plant remains.

The disk harrow (GPD) implement most used by cotton farmers for the destruction of stalks, among the equipment tested showed intermediate performance in sandy soil, compared to DPC-b and SL + T (Table 2).

Its performance, however, was better in clay soil, being comparable to that of more efficient equipment (DCC and DPC-a). This difference in the performance of disk heavy harrow was a result of the stress distribution that were greater in clay soil to be a bit drier and have more cohesion. In this soil, stalks suffered greater damage by mechanical injury, compared to sandy soil and consequently had a higher percentage of dead plants after 60 days.

The equipment with active parts type flat disks cutters, manufacturer "b" failed to get the same performance that flat disk coulter manufacturer "a" in test on sandy soil, although showing the same principle of operation (Table 3).

His performance was lower due to lack of lateral stability presented during the tests. Noted the difficulty that the machine operator had to keep the active parts of the equipment on the rows of plants, requiring him constant course corrections.

Lateral stability of this type of equipment is very important, because the range of action of the disk cutters is narrow. Any lateral deviation of the equipment allows plants to escape unscathed, not suffering the action of the active organs. The lack of stability of the DPC-b was therefore probably the inappropriate angle of attack of the disks and the difficulty centering the equipment presented (excess slack lateral). In the case of clay soil, because of fire, data regret and efficiency in destroying stumps for the DPC-b were lost, unable to compare it with other equipment in this type of soil.

The blade subsoiler jointly with crusher residues $(\mathrm{SL}+\mathrm{T})$ showed performance similar to stalks destruction of the disc harrow and DPC-b, but it turned out better than the blade subsoiler (SL), in trials in sandy soil. The only difference between them is that the SL + T has a crusher plant remains conjugate, mounted in front of the blades in the same equipment. 
The best performance of the equipment conjugate may be attributed to the fact that the blades worked on the root system of stalks simultaneously to the action of crusher, which attacked the shoots, causing a destructive effect on the best stump than mowing and sub soiling on at different times.

The subsoiler blades (S) were the equipment with the lowest efficiency in destroying the stalks of $77.51 \%$ in sandy soil and $88.1 \%$ in clay soil. Its operation in both soils was classified as inefficient.

The results monitoring the implementation of essays propose that the equipment can't stay the whole time aligned with the row of plants and it causes irregularity in its action, allowing the occurrence of failures in the destruction of stalks, especially those devices whose active organ limited in scope, as in the case of flat disks cutters. Even in the case of heavy grade was observed that plants escape unscathed from the action of the disks.

The results allow us to affirm that only equipment DPC-a and DCC would meet the requirement of $98 \%$ efficiency in the destruction of the cotton crop residues on the sandy soil. It is observed in Table 3 that even reducing pattern of stalk destruction efficiency of $95 \%$ for only these two devices continue meeting the requirement. In the case of clayey soil only DCC higher level of efficiency reached $98 \%$.

It is observed in Table 3 that even reducing pattern of stalk destruction efficiency of 95\% for only these two devices continue meeting the requirement. In the case of clayey soil only DCC reached higher level of efficiency of $98 \%$. In this sense it is considered an acceptable re-growth rate less than $2 \%$ to maintain manageable levels, pests and diseases in cotton stalks in any soil condition, just the equipment convergent concave disks reach this index.

Strictly speaking, the results of this analysis lead to think that it is necessary to establish acceptable levels of regret for cotton crops, after the practice of removing crop residues of cotton. No treatment showed $100 \%$ elimination of plants in a single operation. In this way we need to consider, from the point of view of sanitary control, which is the maximum rate of regret to be accepted. This index should be fetched in an attempt to standardize the activities of inspection and sanitary control of the cotton growing areas.

The operational performance of equipment destruction of stalks cotton has different behavior as seen in the analysis of variance, Table 4, where the theoretical field capacity and energy demand had significant $\mathrm{F}$ test between treatments.

The operating performance of a machine or implement does not depend exclusively of the operating principle of your body active. It is necessary that the equipment as a whole, present a suitable project, because even though the operating principle of high efficiency, the machine may fail to perform their work satisfactorily, by design issues. The results obtained by the equipment manufacturer cutters flat disks $\mathrm{A}$ and $\mathrm{B}$ of the manufacturer, and similar devices, which have the same working principle, showed results significantly different in tests (Table 5).

TABLE 4. Summary of analysis of variance for performance indicators of the cotton stalks destroyers valued at sandy soil and clay soils.

\begin{tabular}{|c|c|c|c|c|c|c|c|c|c|}
\hline \multirow{4}{*}{$\begin{array}{c}\text { Source } \\
\text { Variation }\end{array}$} & \multirow{4}{*}{ GL } & \multicolumn{4}{|c|}{ Field theoretical capacity } & \multicolumn{4}{|c|}{ Energy demand $\left(\mathrm{kWh} \mathrm{ha}^{-1}\right)$} \\
\hline & & \multicolumn{4}{|c|}{ Soil Texture } & \multicolumn{4}{|c|}{ Soil Texture } \\
\hline & & \multicolumn{2}{|c|}{ Sandy soil } & \multicolumn{2}{|c|}{ Clayey } & \multicolumn{2}{|c|}{ Sandy soil } & \multicolumn{2}{|c|}{ Clayey } \\
\hline & & $\mathrm{QM}$ & $\mathrm{F}$ & QM & $\mathrm{F}$ & $\mathrm{QM}$ & $\mathrm{F}$ & $\mathrm{QM}$ & $\mathrm{F}$ \\
\hline Trat. & 5 & 13,7 & $660,3^{* *}$ & 14,1 & $1.410^{* *}$ & 938,9 & $400,1^{* *}$ & 862,7 & $957,9 * *$ \\
\hline Erro & 30 & 0,02 & & 0,01 & & 2,35 & & 0,9 & \\
\hline Total & 35 & & & & & & & & \\
\hline
\end{tabular}

* And ${ }^{* *}$ significant at $1 \%$ and $5 \%$ probability of error, respectively, by $\mathrm{F}$ test 
TABLE 5. Performance indicators of the cotton stalks destroyers valued at sandy soil and clay soils.

\begin{tabular}{|c|c|c|c|c|}
\hline \multirow{3}{*}{ Procedures } & \multirow{2}{*}{\multicolumn{2}{|c|}{$\begin{array}{c}\text { Theoretical field capacity }\left(\mathrm{ha} \mathrm{h}^{-1}\right) \\
\text { Texture }\end{array}$}} & \multicolumn{2}{|c|}{ Energy demand $\left(\mathrm{kWh} \mathrm{ha}^{-1}\right)$} \\
\hline & & & \multicolumn{2}{|c|}{ Texture } \\
\hline & Sandy soil & Clay & Sandy soil & Clay \\
\hline DCC & 5,69 Аа & 5,83 Аа & $12,66 \mathrm{Aa}$ & $12,37 \mathrm{Aa}$ \\
\hline DPC-a & 3,96 Ab & 3,51 Bb & $21,45 \mathrm{Ab}$ & $24,17 \mathrm{Bb}$ \\
\hline DPC-b & 3,33 Ac & $2,52 \mathrm{Bc}$ & $25,70 \mathrm{Ac}$ & $33,75 \mathrm{Bc}$ \\
\hline SL & 2,43 Ad & $2,41 \mathrm{Ac}$ & 29,67 Ad & 29,91 Ad \\
\hline $\mathrm{SL}+\mathrm{T}$ & 1,91 Ae & 1,94 Ad & 44,53 Ae & 43,74 Ae \\
\hline GPD & 1,66 Ae & 1,66 Ae & 43,42 Ae & 43,42 Ae \\
\hline
\end{tabular}

Means followed by the same lower case in the column do not differ statistically by the Tukey test ( $<<0.05)$; Means followed by the same capital letter in the line do not differ statistically by t-test $(p<0,05)$. (DPC-a) Flat disk coulter Manufacturer (A), (DPC-b) flat disk coulter (Manufacturer B); (DCC) convergent concave discs; (GPD) Heavy disk harrow; (SL) Subsoiler blade; (SL + T) subsoiler + Crusher plant remains.

The apparatus convergent concave disks showed the greatest field capacity, either in the sandy soil (5.69 h ha-1) as the clay $\left(5.83 \mathrm{~h} \mathrm{ha}^{-1}\right)$ as a result of high speed operation over $3 \mathrm{~m} \mathrm{~s}^{-1}$. This speed was high and exceeded that reported by MANIAN et al. (2004) $0.56 \mathrm{~m} \mathrm{~s}^{-1}$.

The destroyer of stalks by flat disk coulter, the manufacturer (DPCa), also showed a high performance in the destruction of stalks, as shown in Table 5, but its field capacity (3.96 ha h $\mathrm{h}^{-1}$ ) was lower than obtained by convergent concave disk. However, when compared to other equipment, its field capacity was higher.

The equipment flat disks cutters manufacturer B (DPCb) obtained field capacity of $3.33 \mathrm{ha} \mathrm{h}^{-}$ 1 , this lower performance obtained by the same type of machine by manufacturer " a" and the concave disks convergent. The disks maintained their position at ground enough to cut the plants in the region of the neck and had difficulty maintaining the alignment of the ranks, forcing the operator to work on speed a bit lower compared to the manufacturer's equipment "a ".

The subsoiler blades showed capacities field of $2.43 \mathrm{ha} \mathrm{h}^{-1}$, only been superior to subsoiler + Crusher plant remains and heavy disk harrow. The subsoiler + Crusher plant remains, in turn, presented similar to field capacity of the heavy disk harrow, respectively ha $1.91 \mathrm{~h}$ and $1.66 \mathrm{~h}-1$, which are the least field capacity among all equipment tested.

The equipment type subsoiler with active parts of the blade, showed low values of field capacity because they were not developed just for the practice of destroying stalks. Its use is intended to perform the disruption of compacted layers beyond the destruction of stalk. In this way, to evaluate the performance of these implements is to remember that they seek to perform two activities simultaneously. The susoiler + crusher blades intend actually to run three simultaneous operations, which are: crushing aerial parts of the plants, eliminating stalk and proceed to sub soiling. In this sense, we need to consider when seeking comparing their performance in relation to other equipment in those situations in which the disruption of soil layers is necessary.

The type of soil influenced only the flat discs cutters (DPC) equipment, as shown in Table 5. In clay soil, more cohesive, was the largest application of force required to move the disks and the advancement of this equipment. Other equipment showed no difference in the theoretical field capacity between the two soil types studied. In the case of heavy disk, the theoretical field capacity, as might be expected, did not vary among soil types. This occurred because the working width was the same and the working speed varied little. Considering that the tensile force in this case depends only on the weight of the grid (SERRANO, 2007) and the tuning of the tractor were equal, one would expect that there were also differences in velocity between the set two types of soil and 
consequently of field capacity. However, in devices with convergent concave disks (DCC) and subsoilers blades (SL and SL $+\mathrm{T}$ ) that move large volumes of soil, it was expected that the theoretical field capacity was lower in clay soil.

The field capacity was expected because the lower travel speed could be lower due to the increased demand of traction force, which depends on the cohesion (Payne, 1956), which in turn depends on soil texture (ROSA, 2007). This unexpected behavior can result from adjustments and settings working conditions that were not being standardized under the responsibility of the manufacturers of the equipment.

The CCT obtained by equipment of brass knuckles destruction, between 1.66 and 5.69 ha h-1, were higher than those reported by researchers implements for soil preparation and stalk machines. Stalks values of field capacity observed by GARCIA et al. (2011), were 0.16 and 0.29 ha h-1. Already, VALE et al. (2008), succeeded theoretical field capacity of 0.96 ha h-1 for conventional tillage and 1.15 ha h-1 for direct tillage. RODRIGUES et al. (2011) obtained a CCT of 1.1 ha h-1 in soil tillage with disk harrow and $0.83 \mathrm{ha}^{-1}$ for these harrow and $0.83 \mathrm{ha} \mathrm{h}^{-1}$ for chisel plow. These results show that the destruction of cotton stalks is a quick task, compared to other mechanized operations involving soil movement. However, there is the reality that there is reluctance among cotton farmers to undertake this practice prophylaxis in cotton.

After an extensive literature review was not possible to find data on operational capability or energy demand for the elimination of stalk cotton. However it was established that this operation requires more energy than seeding, since the results obtained for almost all equipment tested are superior to those obtained by BORTOLOTTO et al. (2006), working with soybean seeding, and found demand of approximately $15 \mathrm{kWh} \mathrm{ha}^{-1}$. . The exception was the DCC, which thanks to its power demand (used tractor $140 \mathrm{hp}$ ) and high working speed achieved was the one who showed lower values than those obtained by these authors (Table 5).

The equipment with the highest energy demands was the subsoiler blades + crusher blades (44.53 $\mathrm{kWh} \mathrm{ha}^{-1}$ ) and heavy harrow disks (43.42 $\mathrm{kWh} \mathrm{ha}^{-1}$ ), who's results did not differ statistically among themselves, as shown in Table 5. Other equipment showed significant differences in energy demand and disc concave convergent with the lowest demand (12.66 $\left.\mathrm{kWh} \mathrm{ha}^{-1}\right)$, followed by flat disks cutters manufacturer A (24.17 $\mathrm{kWh} \mathrm{ha}^{-1}$ ), flat discs cutters manufacturer B (33.75) $\mathrm{kWh} \mathrm{ha}^{-1}$ ), and subsoiler blades (29.91 $\left.\mathrm{kWh} \mathrm{ha}^{-1}\right)$.

The energy demands of equipment for stalks destruction that mobilize soil varied among $29.91 \mathrm{kWh} \mathrm{ha}^{-1}$ and $44.53 \mathrm{kWh} \mathrm{ha}^{-1}$ being below those obtained by SALVADOR (2009), who reported values of $54.49 \mathrm{kWh} \mathrm{ha}^{-1}$ for soil preparation with disk plow, $53.18 \mathrm{kWh} \mathrm{ha}^{-1}$ for heavy disk harrow and $54.46 \mathrm{kWh} \mathrm{ha}^{-1}$ for chisel plow. However, the values found are close to those obtained by FERNANDES and GAMERO (2010), who obtained demands of $31.06 \mathrm{kWh} \mathrm{ha}^{-1}$ in soil with disk plow and $41.2 \mathrm{kWh} \mathrm{ha}^{-1}$ when using the chisel plow. The pasture renovator rated by Fernandes et al. (2007) showed energy average demand of $35 \mathrm{kWh} \mathrm{ha}^{-1}$. The power demand for equipment of stalks destruction in the cerrado region is high because this practice occurs between July and August, in the middle of the dry season, when the soil is dry.

\section{CONCLUSIONS}

According to the operating conditions of this study, it was concluded that the equipment Concave disks convergent performed better in destroying the stalks cotton, compared to the flat disks cutters, the subsoiler blade and the heavy disk harrow, with greater efficiency in the destruction of stalks.

The heavy disk harrow, the subsoiler blade and flat disks cutters equipment manufacturer "b" showed poor performance for destruction of stalks on sandy soil.

The subsoiler blade was the only equipment whose performance was considered inefficient both in sandy and in clay soil. 
The destruction of the remains of cotton crop is a task that requires high energy demand, of the order from 12.37 to $44.53 \mathrm{~kW} \mathrm{~h} \mathrm{ha}{ }^{-1}$.

\section{REFERÊNCIAS}

BALASTREIRE, L.A. Máquinas agrícolas. Piracicaba: Luis Antonio Balastreire. Ed., 2005. 307 p.

BIANCHINI, A. Destruição de soqueiras de algodão. In: CONGRESSO BRASILEIRO DE ALGODAO, 5., 2005, Salvador: Anais... Campina Grande: Embrapa Algodão; Salvador: ABRAPA 2005. Palestra.

BIANCHINI, A. Protótipo de equipamento para destruição de soqueiras de algodão. In: CONGRESSO BRASILEIRO DE ENGENHARIA AGRÍCOLA, 35., 2006, João Pessoa. Anais... Jaboticabal: Associação Brasileira de Engenharia Agrícola, 2006. CD-ROM.

BORTOLOTTO, V. C.; PINHEIRO NETO, R.; BORTOLOTTO, M. C. Demanda energética de uma semeadora-adubadora para soja sob diferentes velocidades de deslocamento e coberturas do solo. Engenharia Agrícola, Jaboticabal, v. 26 n.1. p. 122-130. 2006.

EMBRAPA. Empresa Brasileira de Pesquisa Agropecuária. Centro Nacional de Pesquisa do Algodão. Manejo integrado de pragas do algodoeiro no cerrado brasileiro. Circular técnica $n^{o} 131$. Campina Grande, 2010. 36p.

EMBRAPA. Centro Nacional de Pesquisa de Solos. Manual de métodos de análise de solos. 2.ed. Rio de Janeiro: Embrapa Produção de Informação, 1997. 212p.

FERNANDES, J. C.; GAMERO, C. A. Avaliação do desempenho das máquinas agrícolas na implantação da cultura do girassol. Revista Energia na Agricultura, Botucatu, vol. 25, n.2, p.74-87, 2010.

FERNANDES, H. C.; MION, R. L.; SILVEIRA, J. C. M.; RINALDI, P. C. N.; MODOLO, A. J. Avaliação da demanda energética numa operação conjugada de preparo do solo. Revista Ceres, Viçosa-MG, v. 54, n.312, p. 132-138, 2007.

GARCIA, R. F.; VALE, W. G.; OLIVEIRA, M. T. R.; PEREIRA, E. M.; AMIM, R. T.; BRAGA, T. C. Influência da velocidade de deslocamento no desempenho de uma semeadora-adubadora de precisão no Norte Fluminense Acta Scientiarum Agronomy, Maringá, v. 33, n. 3, p. 417-422, 2011.

MANIAN, R., KATHIRVEL, K., RAO, M. K., SENTHILKUAMR, T. Efficiency of cotton stalk puller as influenced by forward speed, wheel rotational speed and wheel tilt angle. Agricultural Mechanization in Asia, Africa and Latin America, v. 35, n. 1, p. 37-40, 2004.

MOSTOFI SARKARI, M.R., MINAEE, S. Evaluation of a Cotton Stalk Puller Performance, American-Eurasian Journal. Sustainable. Agriculture, Ma’an, v. 2, n. 1, p. 19-24, 2008.

PAYNE, P. C. J. The relationship between the mechanical properties of soil and performance of simple cultivation implements. Journal of Agricultural Engineering Research, London, v. 1, p. 2350, 1956.

PASSOS, S. M. de G. Algodão. São Paulo. Instituto Campineiro de Ensino Agrícola, 1977. 424 p.

RODRIGUES, J. G. L.; FERNANDES, J. C.; NASCIMENTO, F. M; GAMERO, C. A.; BICUDO, S. J. Caracterização física do solo e desempenho operacional de máquinas agrícolas na implantação da cultura do sorgo forrageiro. Semina: Ciências Agrárias, Londrina, v. 32, sup. 1, p. 1813-1824, 2011.

ROSA, D. da R. Comportamento dinâmico e mecânico do solo sob níveis diferenciados de escarificação e compactação. 2007. 112 f. Dissertação (Mestrado em Engenharia Agrícola) Universidade Federal de Santa Maria, Santa Maria, 2007. 
SAGLAM, C.; KAPLAN, F.; POLAT, R. A study on the chopping and mixing of cotton stalks with soil. African Journal of Biotechnology, Nairob, v. 9, n. 30, p. 4.764-4.775, 2010.

SALVADOR, N.; BENEZ, S. H.; MION, R. L. Demanda energética na subsolagem realizada antes e depois de diferentes sistemas de preparo periódico do solo. Ciência Rural, Santa Maria, v.39, n.9, p.2501-2505, dez, 2009.

SILVA, O. R. R. F., CARVALHO, O. S. VASCONCELOS, O. L., SOARES, J. J., QUEIROZ, J. C. e PAULA, D. F. Avaliação de diferentes métodos de destruição de restos culturais do algodoeiro Revista Brasileira de Engenharia Agrícola e Ambiental, Campina Grande v.3, n.3, p.391-394, 1999.

SERRANO, J. M. P. Desempenho de tratores agrícolas em tração. Pesquisa agropecuária brasileira, Brasília, v.42, n.7, p.1021-1027, jul. 2007.

VALE, W. G.; GARCIA, R. F.; THIEBAUT, J. T. L.; AMIM, R. T.; TOURINO, M. C. C.

Desempenho e dimensionamento amostral para avaliação de uma semeadora adubadora em plantio direto e convencional. Acta Scientiarum Agronomy, Maringá, v. 30, n. 4, p. 441-448, 2008. 